\title{
Acute Sheehan's syndrome manifesting initially with diabetes insipidus postpartum: a case report and systematic literature review
}

\author{
Gregor Leonhard Olmes ${ }^{1}$ - Erich-Franz Solomayer ${ }^{1}$. Julia Caroline Radosa ${ }^{1} \cdot$ Panagiotis Sklavounos $^{1} \cdot$ Philipp Agne $^{2}$. \\ Stefan J. Schunk ${ }^{2}$ Bashar Haj Hamoud ${ }^{1}$
}

Received: 11 May 2021 / Accepted: 13 October 2021 / Published online: 15 November 2021

(c) The Author(s) 2021

\begin{abstract}
Purpose Acute Sheehan's syndrome is a rare, but potentially life-threatening, obstetric event that can be complicated by diabetes insipidus. Little information on the diagnosis and treatment of Sheehan's syndrome with diabetes insipidus is available. We report on a 28-year-old patient who developed acute Sheehan's syndrome with diabetes insipidus after giving birth, and on a systematic review of similar cases.

Methods We performed a systematic review of the literature cataloged in PubMed and Google Scholar using the keywords "Sheehan syndrome" OR "Sheehan's syndrome" AND "diabetes insipidus" to identify relevant case reports published between 1990 and 2021. Eight Reports met the inclusion criteria (English-language abstracts available, onset in the puerperium, information about the day of the onset).

Results In the present case, postpartum curettage was necessary to remove the residual placenta. The total amount of blood loss was severe $(2500 \mathrm{ml})$. On the second day postpartal, the patient developed polyuria. Laboratory analysis revealed hypernatremia with increased serum osmolality and decreased urinary osmolality. Hormone analysis showed partial hypopituitarism involving the thyroid, corticotropic, and gonadotropic axes. The prolactin level was elevated. Brain magnetic resonance imaging showed pituitary gland infarction. Desmopressin therapy was initiated and resolved the polyuria. Hormone replacement therapy was administered. Four months later, the patient was well, with partial diabetes insipidus. The literature review indicated that this case was typical in terms of symptoms and disease onset. Most reported cases involve hypotension and peripartum hemorrhage, but some patients without hemorrhage also develop Sheehan's syndrome. Elevated prolactin levels are uncommon and associated with poor prognosis in patients with Sheehan's syndrome.

Conclusion Acute Sheehan's syndrome with diabetes insipidus involves nearly all pituitary hormone axes, indicating severe disease. Prolactin elevation could suggest that a case of Sheehan's syndrome is severe.
\end{abstract}

Keywords Sheehan's syndrome $\cdot$ Diabetes insipidus $\cdot$ Peripartum hemorrhage $\cdot$ Case report $\cdot$ Prolactin

\section{Introduction}

Sheehan's syndrome is characterized by ischemic necrosis of the anterior pituitary gland after severe postpartum hemorrhage, with hormonal insufficiencies ranging from single pituitary hormone insufficiency to total hypopituitarism [1]. The pituitary gland undergoes physiological enlargement

Gregor Leonhard Olmes

gregor.olmes@uks.eu

1 Department of Gynecology, Obstetrics and Reproductive Medicine, Saarland University Hospital, Homburg, Germany

2 Department of Internal Medicine IV - Nephrology, Saarland University Hospital, Homburg, Germany during pregnancy, with a physiological increase in lactotroph cell mass and hypertrophy of its anterior portion, as determined by autopsies and magnetic resonance imaging (MRI) [2, 3]. Ischemia of the hypertrophied anterior pituitary gland during severe hemorrhage is thought to be the cause of Sheehan's syndrome [4]. The onset of disease ranges from an acute onset in the puerperium to several years after birth [5-7]. The role of autoantibodies remains unclear for etiology [6].

Central diabetes insipidus is a rare complication of Sheehan's syndrome [8-10]. Here, we present the case of a woman with Sheehan's syndrome manifesting initially with central diabetes insipidus in the context of a systematic literature review. 


\section{Case report}

\section{Clinical presentation}

A healthy 28 -year-old primigravida gave birth to a male infant weighing $3030 \mathrm{~g}$ (12th percentile; Apgar score (1-min 9/5-min 10/10-min 10) at 40 gestational weeks in the Department of Gynecology, Obstetrics and Reproductive Medicine, Saarland University Hospital, Homburg, Germany, a tertiary center of perinatal medicine. The delivery occurred without complication with the infant in the left anterior occiput position after mediolateral episiotomy (umbilical artery $\mathrm{pH}$ 7.320, Base excess (BE) - 8.4; umbilical vein $\mathrm{pH} 7.329$, BE - 7.6). Uterotonic medication was administered prophylactically, and the placenta was delivered 23 min after childbirth.

Thereafter, the patient entered shock with hypotension (arterial blood pressure $90 / 50 \mathrm{mmHg}$, heart rate 80 beats per minute) by an atonic bleeding (Table 1). Clinical examination and sonography revealed the presence of residual placenta in the uterine cavity. It was removed by emergency curettage performed under general anesthesia. During this procedure, the patient's arterial blood pressure normalized, ranging from $125 / 80$ to $100 / 50 \mathrm{mmHg}$. The urine production was $125 \mathrm{ml} / \mathrm{h}$.

To treat the atony, we followed the algorithm of the interdisciplinary D-A-CH consensus group PPH 2014 [11]. Oxytocin (Oxytocin 10 I.E. HEXAL ${ }^{\circledR} 10$ I.E./ml), sulprostone (Nalador-500 ${ }^{\circledR}, 500 \mu \mathrm{g}$ sulprostone Jenapharm ${ }^{\circledR}$ ) and misoprostol (Cytotec ${ }^{\circledR} 200 \mu \mathrm{g}$ Misoprostol Tabs Pfizer ${ }^{\circledR}$ ) were administered and a Bakri ${ }^{\circledR}$ balloon catheter (Bakri Postpartum Ballon $\mathrm{COOK}^{\circledR}$ MEDICAL) was placed into the uterine

Table 1 Clinical parameter during shock

\begin{tabular}{ll}
\hline Arterial blood pressure & $90 / 50 \mathrm{mmHg}$ \\
Heart rate & $80 / \mathrm{min}$ \\
Blood loss & $2500 \mathrm{ml}$ \\
Urine production & $125 \mathrm{ml} / \mathrm{h}$ \\
Hemoglobin level preoperatively & $11.8 \mathrm{~g} / \mathrm{dl}$ \\
Hemoglobin level postoperatively & $9.3 \mathrm{~g} / \mathrm{dl}$ \\
\hline
\end{tabular}

cavity for $24 \mathrm{~h}$. The mediolateral episiotomy was repaired with sutures. Tranexamic acid ( $2 \mathrm{~g}$, Cyklokapron ${ }^{\circledR}$ Pfizer $^{\circledR}$ $1000 \mathrm{mg} / 10 \mathrm{ml})$, fibrinogen $\left(2 \mathrm{~g}\right.$, Haemocomplettan ${ }^{\circledR} \mathrm{P} 1 \mathrm{~g}$, CSL Behring ${ }^{\circledR}$ ), and two erythrocyte concentrates (each $300 \mathrm{ml}$ ) were administered perioperatively. The bleeding stopped and the patient's hemoglobin level decreased (to $9.3 \mathrm{~g} / \mathrm{dl}$ from $11.8 \mathrm{~g} / \mathrm{dl}$ preoperatively). The total volume of blood loss was $2500 \mathrm{ml}$ (Table 1).

Postoperatively, the patient was monitored overnight in the department's intermediate care unit. The balloon catheter was removed after $24 \mathrm{~h}$, and the lochia was determined to be normal. The patient was transferred to the postpartal ward the following morning. In the evening of the first postpartal day, the patient reported hot flashes and headache. She could not breastfeed because of agalactorrhea (Table 2). In the morning of the second postpartal day, the patient reported polydipsia (Table 2 ). Her urinary production was 14 1/day $(580 \mathrm{ml} / \mathrm{h})$. The patient was transferred back to the intermediate care unit for monitoring. A central venous catheter was installed to start an infusion with electrolyte solutions $100 \mathrm{ml} /$ hour (Sterofundin ${ }^{\circledR}, 1000 \mathrm{ml} \mathrm{BRAUN}{ }^{\circledR}$ ). Laboratory analysis on the second day after delivery revealed hypernatremia (sodium $148 \mathrm{mmol} / \mathrm{l}$ ), hyperchloremia (chloride $116 \mathrm{mmol} / \mathrm{l})$, serum hyperosmolality (305 mosmol/ $\mathrm{kg}$ ), and decreased urinary osmolality (66 mosmol/ $\mathrm{kg}$ ) (Table 2$)$. The patient's hemoglobin level decreased over the second and third postpartum days to $6.5 \mathrm{~g} / \mathrm{dl}$, and three erythrocyte concentrates (each $300 \mathrm{ml}$ ) were transfused on the third day after delivery (Table 2). After this transfusion, the patient's hemoglobin level stabilized at $8.0 \mathrm{~g} / \mathrm{dl}$.

\section{Diagnostic assessment}

The patient was transferred to the hospital's nephrology department for further diagnostic workup and treatment on the third day after delivery. Polyuria featuring hypernatremia, hyperchloremia, serum hyperosmolality, and decreased urinary osmolality led to the diagnosis of diabetes insipidus. The brain MRI examination performed on the third day after birth revealed mild ischemic infarction of the pituitary gland compatible with Sheehan's syndrome with central diabetes insipidus. (Table 2). Hormonal assessment

Table 2 Timeline of symptoms, diagnostic assessment and therapeutic intervention

\begin{tabular}{llll}
\hline Day after delivery & Symptoms & Diagnostic assessment & Therapeutic intervention \\
\hline $\begin{array}{l}\text { First day } \\
\text { Second day }\end{array}$ & Hot flashes, headache, agalactorrhea & - & - \\
& Polydipsia, polyuria & $\begin{array}{c}\text { Laboratory analysis of sodium, chlo- } \\
\text { ride, osmolality of serum and urine }\end{array}$ & $\begin{array}{l}\text { Infusion with electrolyte solutions } \\
\text { Third day }\end{array}$ \\
Fourth day & Drop of hemoglobin level $6.5 \mathrm{~g} / \mathrm{dl}$, & Brain MRI scan, analysis of hormones & $\begin{array}{l}\text { Transfusion of three erythrocyte concentrates } \\
\text { Desmopressin therapy and hormone replace- } \\
\text { ment }\end{array}$ \\
\hline
\end{tabular}


revealed partial hypopituitarism, including hypothyroidism and Addison's disease (Table 3). Prepartal hormone values were not available. The patient's thyroid-stimulating hormone level was normal $(0.49 \mu \mathrm{IU} / \mathrm{ml})$ and her free $\mathrm{T} 3$ and $\mathrm{T} 4$ levels were low $(1.71 \mathrm{pg} / \mathrm{nl}$ and $0.63 \mu \mathrm{g} / \mathrm{ml}$, respectively). Her cortisol level was in the low normal range $(15.2 \mu \mathrm{g} /$ $\mathrm{dl}$ ), interpreted as reflecting a lack of adrenocorticotropic hormone.

Additional laboratory examinations, including the analysis of sex hormone and gonadotropin levels, were performed in the hospital's endocrinology department on the fourth day after birth. The levels of luteinizing hormone (LH; $<0.1 \mathrm{IU} /$ $\mathrm{ml}$ ) and follicle-stimulating hormone (FSH; $<0.1 \mathrm{mIU} / \mathrm{ml}$ ) were decreased, confirming the patient's postmenopausal status (Table 3). The levels of sex hormones, such as estradiol $(15 \mathrm{pg} / \mathrm{ml})$ and progesterone $(0.238 \mathrm{ng} / \mathrm{ml})$, were low. Additional analysis revealed that the anti-Müllerian hormone level was also low $(0.67 \mathrm{ng} / \mathrm{ml})$. The prolactin level was high $(1033 \mu \mathrm{lU} / \mathrm{ml})$, but the patient remained unable to breastfeed.

\section{Therapeutic intervention}

Daily administration of desmopressin (Nocutil $^{\circledR} 0,1 \mathrm{mg} / \mathrm{ml}$ nasal spray, AGOPHEA ${ }^{\circledR}$ ) starting on the fourth day after delivery as a nasal spray led to a normalized urine production, and thus to a normalized urine and serum osmolality (both $106 \mathrm{mosmol} / \mathrm{kg}$ ). Under the daily treatment, the patient got transient hyponatremia (sodium $122 \mathrm{mmol} / \mathrm{l}$ ), that resolved after a 3-day pause in the desmopressin treatment (sodium $141 \mathrm{mmol} / \mathrm{l}$ ). Thereafter, the treatment was applied depending on polyuria and nycturia. The patient's hypothyroidism was treated with L-thyroxine $(50 \mu \mathrm{g} / \mathrm{day}$, L-thyroxine Henning ${ }^{\circledR}$, Sanof $^{\circledR}$ ) and her Addison's disease was treated with hydrocortisone $(20 \mathrm{mg}$ in the morning, $10 \mathrm{mg}$ at noon, hydrocortisone GALEN ${ }^{\circledR} 10 \mathrm{mg}$ Tabs). A gynecological endocrinologist initiated sequential hormone replacement therapy for the patient with the transdermal application of estradiol gel (Gynokadin ${ }^{\circledR}$ estradiol $0.6 \mathrm{mg} / \mathrm{g}$, twice a day) and additive cyclic oral progesterone (Utrogest ${ }^{\circledR}$ $100 \mathrm{mg}$ progesterone DR. KADE BESINS ${ }^{\circledR}$, two tabs daily) for 12 days every two weeks. This specialist recommended FSH/LH application via hormone pump or pen for future pregnancies. Thirteen days after delivery, the patient was discharged in stable condition.

\section{Follow-up}

The patient underwent regular, in the first week after discharge daily, follow-up examinations in the hospital's ambulatory unit. Six weeks after delivery, her hormone levels had normalized (Table 3). Four months postpartal, the patient felt well and had normal urine production, but also partial diabetes insipidus. This condition was treated with desmopressin nasal spray (twice per day). Her serum sodium concentration and serum and urinary osmolality were normal $(138 \mathrm{mmol} / \mathrm{l}$, $294 \mathrm{mosmol} / \mathrm{kg}$, and $820 \mathrm{mosmol} / \mathrm{kg}$, respectively).

\section{Discussion}

Sheehan's syndrome is a rare complication of pituitary disorders that occurs during pregnancy separate from lymphocytic hypophysitis and silent pituitary adenoma $[12,13]$. It is seldom encountered in developed countries [12]. The prevalence of Sheehan's syndrome amounted from 5.1 per 100 000 women in Iceland in 2009. No patient of these collective showed signs for the involvement of the posterior pituitary gland [14]. Diabetes insipidus in patients with Sheehan's Syndrome occurs in 5\% [13, 15, 16]. For patients with acute Sheehan's Syndrome, an electronic literature search on PubMed and Google Scholar by Matsuzaki et al. could identify 21 cases of patients with Sheehan's Syndrome. Four of these cases presented a diabetes insipidus accompanied by Sheehan's Syndrome [7, 8, 13, 17, 18].

Sheehan and Whitehead reported that most cases of Sheehan's syndrome manifest with anatomical lesions in the posterior pituitary gland and hypothalamic secretory

Table 3 Hormone values postpartum and 6 weeks after birth

\begin{tabular}{|c|c|c|}
\hline Hormone [units] (normal range) & Postpartum & $\begin{array}{l}6 \text { weeks } \\
\text { after birth }\end{array}$ \\
\hline Thyroid-stimulating hormone $[\mu \mathrm{IU} / \mathrm{ml}](0.27-4.20)$ & 0.49 & 0.5 \\
\hline Free T3 [pg/ml] (2.0-4.4) & 1.7 & 2.5 \\
\hline Free T4 [ng/dl] (0.93-1.70) & 0.63 & 1.3 \\
\hline Prolactin $[\mu \mathrm{IU} / \mathrm{ml}](102-496)$ & 1033 & 300 \\
\hline Cortisol $[\mu \mathrm{g} / \mathrm{dl}](6.2-19.4)$ & 15.2 & 31.7 \\
\hline Luteinizing hormone [mIU/ml] (premenopausal 1.0-12.6, postmenopausal 7.7-58.5) & $<0.1$ & 3.8 \\
\hline Follicle-stimulating hormone $[\mathrm{mIU} / \mathrm{ml}]$ (premenopausal 1.7-21.5, postmenopausal 25.8-134.8) & $<0.1$ & 10.1 \\
\hline Estradiol [pg/ml] (premenopausal 12.4-398, postmenopausal <5-138) & 15 & 42.2 \\
\hline
\end{tabular}


neurons [19]. The impairment of antidiuretic hormone secretion, which causes diabetes insipidus, occurs only when a large portion of the neurohypophysis is destroyed $[20,21]$. The degree of polyuria depends on the proportion of the anterior pituitary gland that is functional [21]. Bakiri et al. reported decreased urinary concentration ability in patients with slow-onset postpartum hypopituitarism. They underwent a dehydration test followed by the administration of desmopressin, reflecting a high prevalence of partial diabetes insipidus among patients with Sheehan's syndrome [22]. Isolated diabetes insipidus is described after postpartum hemorrhage [23].

Diabetes insipidus apart from Sheehan's syndrome is rare during pregnancy and is caused by the increased placental production of vasopressinase, which inactivates circulating vasopressin [24]. This condition is usually transient and disappears a few days after delivery [24].

We performed a systematic review of the literature cataloged in PubMed and Google Scholar using the keywords "Sheehan syndrome" OR "Sheehan's syndrome" AND "diabetes insipidus" to identify relevant case reports published between 1990 and 2021. The search yielded 32 PubMed entries and 838 Google Scholar entries. From these, we selected articles with at least English-language abstracts available that described cases of acute Sheehan syndrome with onset in the puerperium in combination with diabetes insipidus. Information about the day of the onset was mandatory.

Eight reports were included in the analysis, each of them describing one patient [8,10,13, 17, 18, 25-27].

The following data were extracted from the reports: patient age; gravida/para status; mode of delivery; amount of blood loss described as normal or severe; cause of hemorrhage, hypotension, or shock; interval from birth to symptom onset; presence of polyuria; presence of symptoms including headache, fatigue, and agalactorrhea; other hormone disorders (e.g., hypothyroidism, adrenal insufficiency, hypogonadism, hypoprolactinemia, somatotropic axis failure); prolactin level; performance of brain MRI or computed tomography (CT) examination; treatment of diabetes insipidus; and follow-up assessment/treatment.

The characteristics of the cases are summarized in Table 4. Eight patients were included in the review. Patient age was provided in seven case reports $[8,10,13,17,18$, $25,27]$. The median patient age was 34.8 (range, 24-45) years, thus older than our patient. Our case is related to a primigravida with vaginal delivery. Five reports described the patents' gravida/para status; the latter ranged from primipara to multipara $[8,10,17,25,27]$. Twins were delivered in two cases $[10,17]$. The delivery mode was reported for seven cases; four patients delivered by caesarian section and three had vaginal deliveries $[8,10,13$, $17,18,25,27]$.
The estimated blood loss was reported for all cases, and ranged from normal (two cases) $[13,25]$ to severe hemorrhage (six cases) $[8,10,17,18,25,27]$. The term normal is defined as blood loss due $500 \mathrm{ml}$ for a vaginal birth and due $1000 \mathrm{ml}$ for caesarean section according to German guidelines [28]. A hemorrhage of $500-1500 \mathrm{ml}$ is usually tolerated without symptoms of shock or hypotension [29, 30]. In line with the majority of reported cases, our case presented a severe hemorrhage with an estimated blood loss of $2500 \mathrm{ml}$. The hemorrhage required a transfusion immediately perioperatively and three days postpartal. Sheehan's Syndrome is usually seen after severe peripartal hemorrhage with shock and hypotension $[1,31]$.

Four reports described the reasons for hemorrhage, which included the retention of placental fragments and/or atonic bleeding (as in our case), persistent bleeding from the uterus, and amniotic fluid syndrome [8, 10, 18, 27].

Six patients experienced hypotension or shock $[8,10,13$, $18,26,27]$ as in our case too and one patient had no hypotension [25]; no information on this factor was available for the remaining patient [17]. One patient had hypotension during epidural anesthesia, which has been described as a cause of Sheehan's syndrome [13].

The interval between birth and the initial manifestation of symptoms, reported in all cases, ranged from $24 \mathrm{~h}$ to 19 days after delivery $[8,10,13,17,18,25-27]$. The median was 8,8 days. Our patient developed symptoms during the first $24 \mathrm{~h}$.

Seven patients had polyuria $[8,10,13,17,18,25,26]$; no information on this factor was provided for the remaining patient [27]. Other symptoms were reported for four cases; they included headache $(n=4)$, fatigue $(n=2)$, agalactorrhea $(n=3)$, photophobia $(n=1)$, thirst $(n=1)$, and amenorrhea $(n=1)[10,13,25,26]$. Headache has been described as a main symptom of sellar mass apoplexy in patients with Sheehan's syndrome [13]. In line with the symptoms mentioned above, our patient complained about headache, agalactorrhea and hot flushes, followed by polyuria and polydipsia on the day after.

Accompanying hormone disorders were described in five cases $[10,13,18,25,27]$. They were hypothyroidism $(n=3)$, adrenal insufficiency $(n=4)$, hypogonadism $(n=4)$, hypoprolactinemia $(n=3)$, somatotropic axis failure $(n=1)$, and panhypopituitarism $(n=1)$. Of these, our case demonstrated hypothyroidism, adrenal insufficiency and hypogonadism and in contrast hyperprolactinemia.

Patients' prolactin levels were reported for five cases; they were low in four cases $[8,10,13,25]$ and elevated in one case, in which the patient had severe peripartum hemorrhage leading to chronic kidney disease [18]. Prolactin levels are typically low in patients with Sheehan's syndrome [32]; the elevated levels found in the single previously reported case and in our case are atypical and may be associated with 


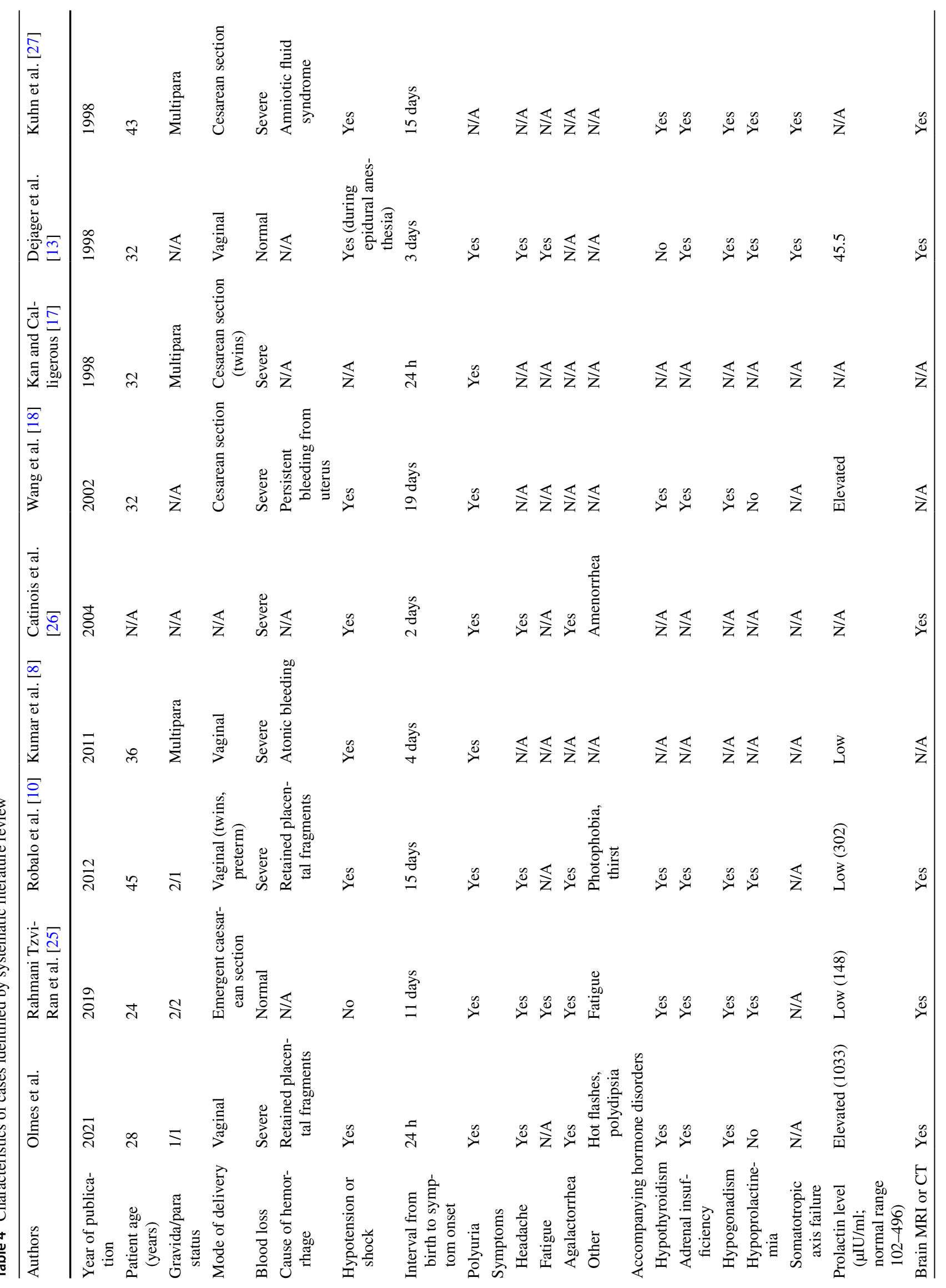




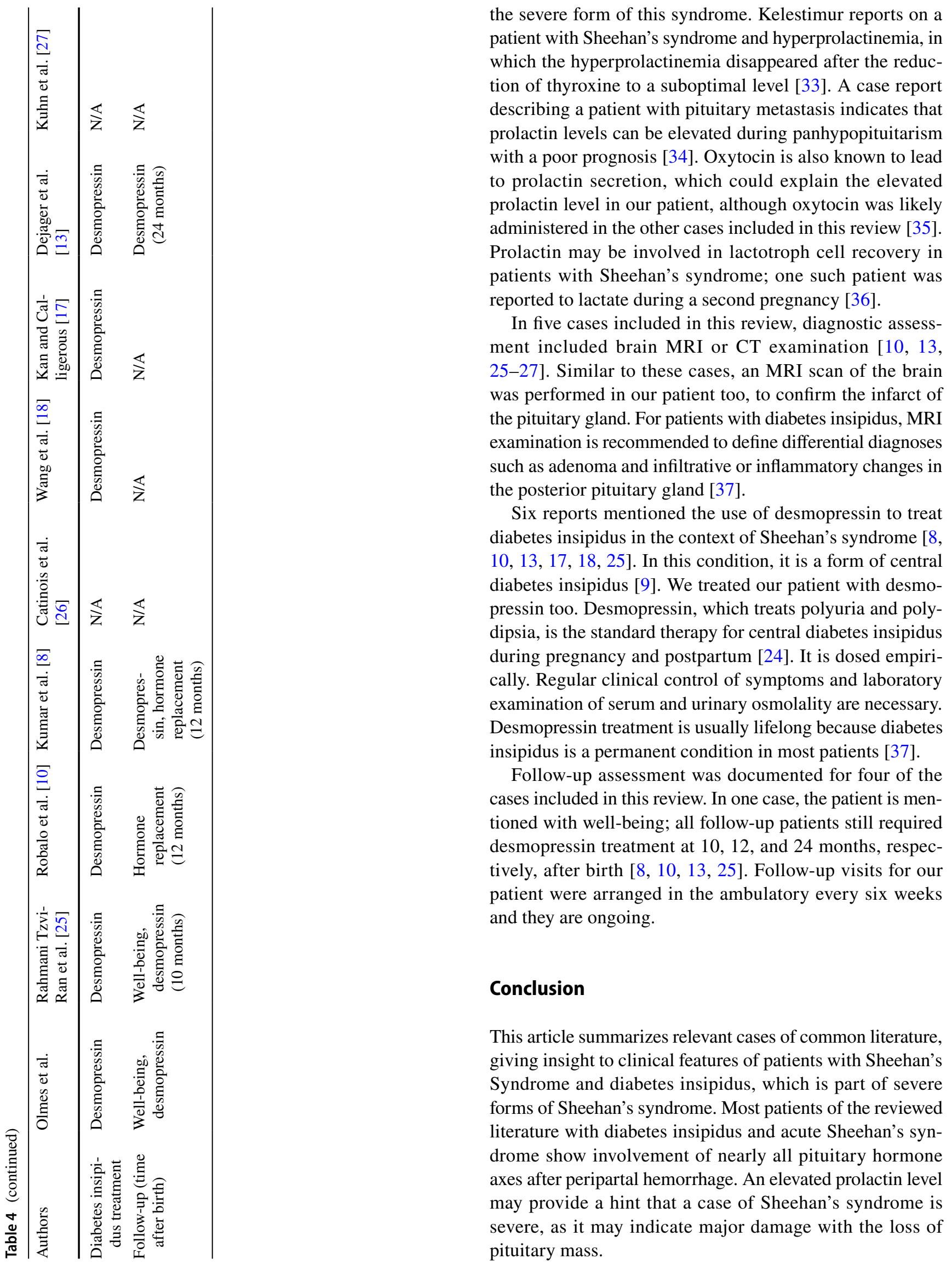

the severe form of this syndrome. Kelestimur reports on a patient with Sheehan's syndrome and hyperprolactinemia, in which the hyperprolactinemia disappeared after the reduction of thyroxine to a suboptimal level [33]. A case report describing a patient with pituitary metastasis indicates that prolactin levels can be elevated during panhypopituitarism with a poor prognosis [34]. Oxytocin is also known to lead to prolactin secretion, which could explain the elevated prolactin level in our patient, although oxytocin was likely administered in the other cases included in this review [35]. Prolactin may be involved in lactotroph cell recovery in patients with Sheehan's syndrome; one such patient was ported to lactate during a second pregnancy [36]

In five cases included in this review, diagnostic assessment included brain MRI or CT examination [10, 13, 25-27]. Similar to these cases, an MRI scan of the brain was performed in our patient too, to confirm the infarct of the pituitary gland. For patients with diabetes insipidus, MRI examination is recommended to define differential diagnoses ch as adenoma and infiltrative or inflammatory changes in

Six reports mentioned the use of desmopressin to treat diabetes insipidus in the context of Sheehan's syndrome [8, $0,13,17,18,25]$. In this condition, it is a form of central pressin too. Desmopressin, which treats polyuria and polydipsia, is the standard therapy for central diabetes insipidus during pregnancy and postpartum [24]. It is dosed empirioratory Desmopressin treatment is usually lifelong because diabetes

Follow-up assessment was documented for four of the cases included in this review. In one case, the patient is menioned with well-being; all follow-up patients still required desmopressin treatment at 10, 12, and 24 months, respecively, after birth $[8,10,13,25]$. Follow-up visits for our patient were arranged in the ambulatory every six weeks and they are ongoing.

pituitary mass. 
Acknowledgements The authors thank Dr. Jennifer Piehl for assistance in editing the final draft of this manuscript.

Author contributions GLO: manuscript writing, data analysis and data management. E-FS: Project development and manuscript editing. JCR: manuscript editing. PS: manuscript editing. PA: manuscript editing. SJS: manuscript editing. BHH: project development and manuscript editing

Funding Open Access funding enabled and organized by Projekt DEAL.

Availability of data and material The dataset used and analyzed during the current study is available from the corresponding author on reasonable request.

Code availability Not applicable.

\section{Declarations}

Conflict of interest The authors declare the following conflicts of interests. E.-F.Solomayer is receiving: grants from the University of Saarland, and Storz and Erbe; personal fees and other compensation from Roche (Basel, Switzerland), Pfizer (New York City, NY, USA), Celgene (Summit USA), Amgen (Thousand Oaks, CA, USA), and Astra Zeneca (Cambridge, UK); and other fees from Esai (Tokyo, Japan), Johnson \& Johnson (New Brunswick, NJ, USA), Novartis (Basel, Switzerland), Tesaro (Waltham, MA, USA), Teva (Petach Tikwa, Israel), Medac GmbH (Wedel, Germany), MSD (Kenilworth, NJ, USA), Vifor (Sankt Gallen, Switzerland), Gedeon Richter (Budapest, Hungary), Takeda (Tokyo, Japan), and AGE (Buchholz, Germany); other potential conflicts: Clovis Oncology (Boulder, Colorado, USA), Genomic Health (Redwood City, California, USA), Jenapharm (Jena, Germany), Matramed (Bexbach, Germany), Mentor (Minneapolis, Minnesota, USA), Pharma Mar (Mardid, Spain), Samsung (Suwon, Southkorea), University of Saarland (Saarbrücken, Germany), DGGG (Berlin, Germany), AGO (Taufkirchen, Germany), AGUB (Taufkirchen, Germany), DGS (Berlin, Germany), DKG (Berlin, Germany), Saarländisches Tumorzentrum am UKS e.V., University of Saarland, Homburg, Germany), Saarländische Krebsgesellschaft (Saarbrücken, Germany), Stiftung Endometriose Forschung (Westerstede, Germany), ESGE (Leuven, Belgium), ETC (Saarbrücken, Germany), DEGUM (Berlin, Germany), Deutsche Kontinenzgesellschaft (Frankfurt, Germany), BLFG (Berlin, Germany), Medconcept (Neustadt an der Weinstraße, Germany), Thieme (Stuttgart, Germany). GL Olmes, JC Radosa, P Sklavounos, P Agne, SJ Schunk, B Haj Hamoud do not have conflicts of interests.

\section{Ethics approval Waiver.}

\section{Consent to participate Waiver.}

Consent for publication Written informed consent was obtained from the patient for publication of this case report.

Open Access This article is licensed under a Creative Commons Attribution 4.0 International License, which permits use, sharing, adaptation, distribution and reproduction in any medium or format, as long as you give appropriate credit to the original author(s) and the source, provide a link to the Creative Commons licence, and indicate if changes were made. The images or other third party material in this article are included in the article's Creative Commons licence, unless indicated otherwise in a credit line to the material. If material is not included in the article's Creative Commons licence and your intended use is not permitted by statutory regulation or exceeds the permitted use, you will need to obtain permission directly from the copyright holder. To view a copy of this licence, visit http://creativecommons.org/licenses/by/4.0/.

\section{References}

1. Sheehan HL (1938) Post-partum necrosis of the anterior pituitary. Trans Edinb Obstet Soc 58:13-28

2. Gonzalez JG, Elizondo G, Saldivar D et al (1988) Pituitary gland growth during normal pregnancy: an in vivo study using magnetic resonance imaging. Am J Med 85:217-220. https://doi.org/10. 1016/s0002-9343(88)80346-2

3. Thorner MO (1990) Changes in the anatomy and function of the maternal anterior pituitary gland during pregnancy. Mayo Clin Proc 65:597-599. https://doi.org/10.1016/s0025-6196(12)60958-6

4. Kilicli F, Dokmetas HS, Acibucu F (2013) Sheehan's syndrome. Gynecol Endocrinol Off J Int Soc Gynecol Endocrinol 29:292295. https://doi.org/10.3109/09513590.2012.752454

5. Dökmetaş HS, Kilicli F, Korkmaz S, Yonem O (2006) Characteristic features of 20 patients with Sheehan's syndrome. Gynecol Endocrinol 22:279-283. https://doi.org/10.1080/0951359060 0630504

6. González-González JG, Borjas-Almaguer OD, Salcido-Montenegro A et al (2018) Sheehan's syndrome revisited: underlying autoimmunity or hypoperfusion? Int J Endocrinol 2018:1-8. https:// doi.org/10.1155/2018/8415860

7. Matsuzaki S, Endo M, Ueda Y et al (2017) A case of acute Sheehan's syndrome and literature review: a rare but life-threatening complication of postpartum hemorrhage. BMC Pregnancy Childbirth 17:188. https://doi.org/10.1186/s12884-017-1380-y

8. Kumar S, Burrows D, Dang S, Simmons D (2011) Sheehan syndrome presenting as central diabetes insipidus: a rare presentation of an uncommon disorder. Endocr Pract Off J Am Coll Endocrinol Am Assoc Clin Endocrinol 17:108-114. https://doi.org/10.4158/ EP10015.CR

9. Laway BA, Mir SA, Dar MI, Zargar AH (2011) Sheehan's syndrome with central diabetes insipidus. Arq Bras Endocrinol Metabol 55:171-174. https://doi.org/10.1590/S0004-2730201100 0200010

10. Robalo R, Pedroso C, Agapito A, Borges A (2012) Acute Sheehan's syndrome presenting as central diabetes insipidus. BMJ Case Rep. https://doi.org/10.1136/bcr-2012-007022

11. Schlembach D, Mörtl MG, Girard T et al (2014) Management der postpartalen Blutung $(\mathrm{PPH})$ : Algorithmus der Interdisziplinären D-A-CH-Konsensusgruppe PPH (Deutschland-ÖsterreichSchweiz). Anaesthesist 63:234-242. https://doi.org/10.1007/ s00101-014-2291-1

12. Chanson $P$ (2019) Other pituitary conditions and pregnancy. Endocrinol Metab Clin North Am 48:583-603. https://doi.org/ 10.1016/j.ecl.2019.05.005

13. Dejager G, Foubert T (1998) Sheehan's syndrome: differential diagnosis in the acute phase. J Intern Med 244:261-266. https:// doi.org/10.1046/j.1365-2796.1998.00370.x

14. Kristjansdottir HL, Bodvarsdottir SP, Sigurjonsdottir HA (2011) Sheehan's syndrome in modern times: a nationwide retrospective study in Iceland. Eur J Endocrinol 164:349-354. https://doi.org/ 10.1530/EJE-10-1004

15. Weiner P, Ben-Israel J, Plavnick L (1979) Sheehan's syndrome with diabetes insipidus. A case study. Isr J Med Sci 15:431-433

16. Collins ML, O'Brien P, Cline A (1979) Diabetes insipidus following obstetric shock. Obstet Gynecol 53:16S-17S 
17. Kan AKS, Calligerous D (1998) A case report of sheehan syndrome presenting with diabetes insipidus. Aust N Z J Obstet Gynaecol 38:224-226. https://doi.org/10.1111/j.1479-828X.1998. tb03009.x

18. Wang H-Y, Chang C-T, Wu M-S (2002) Postpartum hemorrhage complicated with irreversible renal failure and central diabetes insipidus. Ren Fail 24:849-852. https://doi.org/10.1081/JDI120015686

19. Sheehan HL, Whitehead R (1963) The neurohypophysis in postpartum hypopituitaris. J Pathol Bacteriol 85:145-169. https://doi. org/10.1002/path.1700850115

20. Jialal I, Desai RK, Rajput MC (1987) An assessment of posterior pituitary function in patients with Sheehan's syndrome. Clin Endocrinol (Oxf) 27:91-95. https://doi.org/10.1111/j.1365-2265. 1987.tb00843.x

21. Sloper JC (1963) Sheehan's syndrome and diabetes insipidus. BMJ 1:1679-1679. https://doi.org/10.1136/bmj.1.5346.1679-b

22. Bakiri F, Benmiloud M (1984) Antidiuretic function in Sheehan's syndrome. BMJ 289:579-580. https://doi.org/10.1136/bmj.289. 6445.579

23. Adali E, Kucukaydin Z, Adali F, Yildizhan R (2011) Isolated impairment of posterior pituitary function secondary to severe postpartum haemorrhage due to uterine rupture. Gynecol Endocrinol 27:541-542. https://doi.org/10.3109/09513590.2010. 501877

24. Chanson P, Salenave S (2016) Diabetes insipidus and pregnancy. Ann Endocrinol 77:135-138. https://doi.org/10.1016/j.ando.2016. 04.005

25. Rahmani Tzvi-Ran I, Olchowski J, Fraenkel M et al (2019) A rare cause of postpartum acute hyponatremia. Endocrinol Diabetes Metab Case Rep. https://doi.org/10.1530/EDM-18-0124

26. Catinois M-L, Chabre O, Chirossel C et al (2004) Le syndrome de Sheehan : un diagnostic difficile en post-partum immédiat. Ann Fr Anesth Réanim 23:508-512. https://doi.org/10.1016/j.annfar. 2004.01.016

27. Kuhn W, Krauß T (1998) Das Sheehan-Syndrom, eine fast vergessene schwere Komplikation post partum. Geburtshilfe Frauenheilkd 58:336-342. https://doi.org/10.1055/s-2007-1022724

28. Schlembach D (2016) Peripartale Blutungen, Diagnostik und Therapie ; AWMF-Registernummer 015/063 Leitlinienklasse S2k. https://www.awmf.org/uploads/tx_szleitlinien/015-0631_
S2k_Peripartale_Blutungen_Diagnostik_Therapie_PPH_201604.pdf. Accessed 7 Aug 2021

29. Bouwmeester FW, Bolte AC, van Geijn HP (2005) Pharmacological and surgical therapy for primary postpartum hemorrhage. Curr Pharm Des 11:759-773. https://doi.org/10.2174/1381612053 381882

30. Schlembach D, Mörtl MG (2010) Postpartale Hämorrhagie Von der Definition über die Klinik zur Diagnose. Speculum Zeitschrift für Gynäkologie und Geburtshilfe 28(1):5-9. https:// www.kup.at/kup/pdf/8662.pdf. Accessed 20 Feb 2021

31. Diri H, Karaca Z, Tanriverdi F et al (2016) Sheehan's syndrome: new insights into an old disease. Endocrine 51:22-31. https://doi. org/10.1007/s12020-015-0726-3

32. Mandal S, Mukhopadhyay P, Banerjee M, Ghosh S (2020) Clinical, endocrine, metabolic profile, and bone health in sheehan's syndrome. Indian J Endocrinol Metab 24:338. https://doi.org/10. 4103/ijem.IJEM_345_20

33. Kelestimur F (1992) Hyperprolactinemia in a patient with Sheehan's syndrome. South Med J 85:1008-1010. https://doi.org/10. 1097/00007611-199210000-00019

34. Liu CY, Wang YB, Zhu HQ et al (2021) Hyperprolactinemia due to pituitary metastasis: a case report. World J Clin Cases 9:190 196. https://doi.org/10.12998/wjcc.v9.i1.190

35. UvnäsMoberg K, Ekström-Bergström A, Buckley S et al (2020) Maternal plasma levels of oxytocin during breastfeeding - a systematic review. PLoS ONE 15:e0235806. https://doi.org/10.1371/ journal.pone.0235806

36. Laway B, Mir S, Zargar A (2013) Recovery of prolactin function following spontaneous pregnancy in a woman with Sheehan's syndrome. Indian J Endocrinol Metab 17:696. https://doi.org/10. 4103/2230-8210.123571

37. Christ-Crain M, Winzeler B, Refardt J (2021) Diagnosis and management of diabetes insipidus for the internist: an update. J Intern Med. https://doi.org/10.1111/joim.13261

Publisher's Note Springer Nature remains neutral with regard to jurisdictional claims in published maps and institutional affiliations. 